\title{
Penyelesaian Penyalahgunaan Wewenang yang Menimbulkan Kerugian Negara Menurut Hukum Administrasi Pemerintahan
}

\author{
Marojahan JS Panjaitan \\ Sekolah Tinggi Hukum Bandung \\ Jln. Cihampelas Nomor 8 Kota Bandung 40116 \\ marojohanpanjaitan541@gmail.com
}

\begin{abstract}
Received: 3 Juni 2017; Accepted: 26 Desember 2017; Published: 28 Februari 2018
\end{abstract}
DOI: 10.20885/iustum.vol24.iss3.art5

\begin{abstract}
After the issuance of Law Number 30 of 2014, there is an assumption that in the context of misuse of authority causing state losses and once the losses are restored, the problem is considered to have been solved. However, according to Article 4 of Law Number 31 of 1999, the return of state losses does not eliminate the criminal liability. This study examined how to resolve the misuse of authority that causes state financial losses according to the perspective of government administration and coruption law. This was a normative research using juridical-normative and philosophical analysis methods. The results showed that the return of state losses does not eliminate the criminal liability. The perpetrators still have the liability for their criminal actions. Administrative minutes of inspection shall be used as evidence in the criminal case.
\end{abstract}

Keywords: Misuse Misuse of Authority; State Losses; State Finances

\section{Abstrak}

Pasca terbitnya Undang-Undang Nomor 30 Tahun 2014, ada asumsi berkembang bahwa dalam penyalahgunaan wewenang yang menyebabkan kerugian negara dan kerugiannya dikembalikan persoalan menjadi selesai. Padahal, menurut Pasal 4 Undang-Undang Nomor 31 Tahun 1999, pengembalian kerugian negara tidak menghapus pertanggungjawaban pidananya. Penelitian ini mengkaji bagaimana menyelesaikan penyalahgunaan wewenang yang merugikan keuangan negara dalam persfektif hukum administrasi pemerintahan dan tindak pidana korupsi. Penelitian ini merupakan penelitian normatif yang menggunakan metode analisis yuridis normatif dan filosofis. Hasil penelitian menemukan, pengembalian kerugian negara tidak menghapus hukuman pidananya. Pelaku tetap harus mempertanggungjawabkan perbuatannya secara pidana. Berkas pemeriksaan secara administratif digunakan sebagai bukti dalam perkara pidananya.

Kata-kata Kunci: Penyalahgunaan Wewenang; Kerugian Negara; Keuangan Negara 


\section{Pendahuluan}

Berdasarkan ketentuan UUD 1945, sistem penyelenggaraan pemerintahan negara Republik Indonesia didasarkan pada prinsip kedaulatan rakyat dan negara hukum, yang sering disebut dengan demokrasi konstitusional. ${ }^{1}$ H.M. Soerya Respationo $^{2}$ mengatakan bahwa salah satu tumpuan pelaksanaan penyelenggaraan negara itu ada pada birokrasi pemerintah. Birokrasi pemerintah diharapkan mampu memberikan pelayanan publik yang baik kepada masyarakat tanpa diskriminatif. Sjahrudin Rasul ${ }^{3}$ kemudian mengatakan bahwa kepemerintahan yang baik (good governance), merupakan isu yang mengemukan dalam pengelolaan administrasi publik. Hal ini antara lain tercermin dari tuntutan yang gencar dari masyarakat kepada para penyelenggara negara, baik di pemerintahan, dewan perwakilan rakyat mupun yudikatif untuk menyelenggarakan pemerintahan yang baik.

Berdasarkan prinsip-prinsip tersebut di atas, segala bentuk Keputusan dan/atau Tindakan Administrasi Pemerintahan harus berdasarkan demokrasi konstitusional yang merupakan refleksi dari Pancasila sebagai ideologi negara. Keputusan dan/atau Tindakan terhadap warga masyarakat harus sesuai dengan ketentuan peraturan perundang-undangan dan asas-asas umum pemerintahan yang baik. Pengawasan terhadap Keputusan dan/atau Tindakan merupakan pengujian terhadap perlakuan kepada warga masyarakat yang terlibat telah diperlakukan sesuai dengan hukum dan memerhatikan prinsip-prinsip perlindungan hukum yang secara efektif dapat dilakukan oleh lembaga negara dan Peradilan Tata Usaha Negara (PTUN) yang bebas dan mandiri. ${ }^{4}$ Oleh karena itu, sistem dan prosedur penyelenggaraan tugas pemerintahan dan pembangunan harus diatur dalam undang-undang. Untuk itu, diterbitkanlah UU Nomor 30 Tahun 2014 tentang Administrasi Pemerintahan sebagai pedoman dalam menjalankan administrasi pemerintahan. Di dalam Pasal 3 huruf c UU Nomor 30

\footnotetext{
${ }^{1}$ Marojahan JS Panjaitan, Pembentukan \& Perubahan Undang-Undang Berdasarkan UUD 1945, Pustaka Reka Cipta, Bandung, 2017, hlm. 91.

2 H.M. Soerya Respationo, "Penyelenggaraan Pemerintah yang Bersih Menuju Zona Integritas Wilayah Bebas Korupsi”, Jurnal Masalah-Masalah Hukum, Fakultas Hukum Universitas Diponegoro, Jilid 42 No. 1 Tahun 2013, hlm. 115.

3 Sjahrudin Rasul, "Penerapan Good Governance di Indonesia dalam Upaya Pencegahan Tindak Pidana Korupsi”, Jurnal Mimbar Hukum, Volume 21 Nomor 3, Oktober 2009, hlm. 9.

${ }^{4}$ Riawan Tjandra, Teori dan Praktik Peradilan Tata Usaha Negara, Cahaya Atma Pustaka, Yogyakarta, 2011, hlm. 1. Lihat pula Zairin Harahap, Hukum Acara Peradilan Tata Usaha Negara, PT. RajaGrafindo Persada, Jakarta, 2010, hlm. 19.
} 
Tahun 2014 dikatakan bahwa tujuan undang-undang ini dibentuk adalah untuk mencegah terjadinya penyalahgunaan wewenang. Itu artinya bahwa undangundang ini secara tegas melarang segala bentuk penyalahgunaan wewenang.

Terhadap penyalahgunaan wewenang itu di dalam Undang-Undang Nomor 30 Tahun 2014 diatur mekanisme penyelesaiannya. Dalam hal ini, dibentuk Aparat Pengawasan Intern Pemerintah (APIP) 5 . Apabila APIP menemukan ada kesalahan administratif yang menimbulkan kerugian negara (Pasal 20 ayat (2) huruf c), kerugian negara itu harus dikembalikan paling lama 10 hari kerja terhitung sejak diputuskan dan diterbitkannya hasil pengawasan (Pasal 20 ayat (4). Pengembalian kerugian negara itu dibebankan kepada pejabat pemerintahan, apabila kesalahan administrasi karena ada penyalahgunaan wewenang (Pasal 20 ayat (6)). Berkaitan dengan hal itu, menurut Pasal 21 Undang-Undang Nomor 30 Tahun 2014 bahwa Pengadilan Tata Usaha Negara juga berwenang untuk memeriksa dan memutus ada atau tidak ada unsur penyalahgunaan wewenang yang dilakukan oleh pejabat pemerintahan. Tetapi, di luar yang disebutkan di atas, menurut ketentuan UndangUndang Nomor 1 Tahun 2004 tentang Perbendaharaan Negara, yang menentukan terjadi kerugian negara itu adalah BPK.

Adanya penyelesaian penyalahgunaan wewenang yang menimbulkan kerugian negara sebagaimana disebutkan di atas, seakan aparat penegak hukum lain, seperti Kepolisian, Kejaksaan, dan KPK tidak boleh lagi mengusutnya. Padahal, seperti dikemukakan dalam Pasal 4 Undang-Undang Nomor 31 Tahun 1999 tentang Pemberantasan Tindak Pidana Korupsi, bahwa pengembalian kerugian keuangan negara atau perekonomian negara tidak menghapuskan dipidananya pelaku tindak pidana. Pelaku tetap harus mempertanggungjawabkan perbuatannya secara pidana.

Kalau begitu untuk apa kerugian negara itu dikembalikan kalau pelakunya tetap dihukum? Bukankah sifat melawan hukumnya terletak pada kerugian negara? Ketika kerugian negaranya sudah dikembalikan, berarti sifat melawan hukumnya seharusnya sudah hapus. Sebagai pembanding, dapat dilihat ketentuan Pasal 62 ayat (2) Undang-Undang Nomor 1 Tahun 2004 di mana dikatakan apabila

${ }^{5}$ Pasal 20 UU No. 30 Tahun 2014. 
dalan pemeriksaan kerugian negara/daerah ditemukan unsur pidana, Badan Pemeriksa Keuangan menindaklanjutinya sesuai dengan peraturan perundangundangan yang ada. Hal ini menarik untuk dikaji, karena perlu penjelasan tentang keberadaan pengembalian kerugian negara itu dalam perspektif hukum administrasi pemerintahan maupun dalam penanggulangan tindak pidana korupsi.

\section{Rumusan Masalah}

Permasalahan yang akan diteliti dalam penelitian ini adalah bagaimana menyelesaikan penyalahgunaan wewenang yang merugikan keuangan negara dalam perspektif hukum administrasi pemerintahan dan tindak pidana korupsi?

\section{Tujuan Penelitian}

Penelitian ini bertujuan untuk meneliti dan mengkaji bagaimana menyelesaikan penyalahgunaan wewenang yang merugikan keuangan negara dalam persfektif hukum administrasi pemerintahan dan tindak pidana korupsi.

\section{Metode Penelitian}

Jenis penelitian ini adalah penelitian hukum normatif. Sesuai dengan tujuan penelitian ini, sifat penelitiannya adalah penelitian deskriptif analitis, yaitu dengan cara memberikan gambaran atau uraian mengenai permasalahan di dalam penelitian ini. Selanjutnya, metode penelitian yang digunakan disesuaikan dengan rumusan masalah yang menjadi fokus penelitian ini, yakni bagaimana menyelesaikan penyalahgunaan wewenang yang merugikan keuangan negara dalam persfektif hukum administrasi pemerintahan dan tindak pidana korupsi. Pendekatan hukum normatif dilakukan karena dalam menyelesaikan penyalahgunaan wewenang yang merugikan keuangan negara dalam perspektif hukum administrasi pemerintahan dan tindak pidana korupsi sebagai kaidah dan norma hukum merupakan permasalahan hukum yang bersifat normatif namun tidak bisa dipisahkan dari masalah politik, ekonomi, dan sebagainya. Karena itu, pendekatan yuridis-analitis tetap merupakan titik berat penelitian ini.

Pendekatan filosofis digunakan bertalian dengan penerapan UU Nomor 30 Tahun 2014 dalam penanggulangan tindak pidana korupsi di Indonesia, apakah penerapan Undang-Undang Nomor 30 Tahun 2014 tidak bertentangan dengan 
prinsip-prinsip hukum pidana dalam penanggulangan tindak pidana korupsi, tentu hal itu harus mencerminkan rasa keadilan bagi masyarakat di Indonesia.

\section{Hasil Penelitian dan Pembahasan}

\section{Wewenang Pemerintah}

Istilah wewenang atau kewenangan dalam bahasa Inggris disebut authority, dan dalam bahasa Belanda disebut bevoegdheid. Dalam Kamus Besar Bahasa Indonesia, wewenang diartikan sebagai: pertama, hak dan kekuasaan untuk bertindak; kewenangan; Kedua, kekuasaan membuat keputusan, memerintah, dan melimpahkan tanggung jawab. ${ }^{6}$

Authority dalam Black'S Law Dictionary diartikan sebagai Legal power; a right to command or to act; the right and power of public officers to require obedience to their orders lawfully issued in scope of their public duties. ${ }^{7}$ Mohammad Sahlan ${ }^{8}$ mengemukakan bahwa istilah wewenang dan kewenangan selalu dikaitkan dengan "hak dan kekuasaan untuk bertindak atau melakukan sesuatu. Pendapat ini sesuai dengan ketentuan Pasal 1 angka 5 UU Nomor 30 Tahun 2014 yang mengatakan, bahwa: "Wewenang adalah hak yang dimiliki oleh Badan dan/atau Pejabat Pemerintahan atau penyelenggara negara lainnya untuk mengambil keputusan dan/atau tindakan dalam penyelenggaraan pemerintahan." Selanjutnya di dalam Pasal 1 angka 6 disebutkan, bahwa "Kewenangan Pemerintahan yang selanjutnya Kewenangan adalah kekuasaan Badan dan/atau Pejabat Pemerintahan atau penyelenggara negara lainnya untuk bertindak dalam ranah publik."

Bertalian dengan uraian di atas, tampak bahwa wewenang itu merupakan kekuasaan (hak) yang diberikan kepada pejabat publik atau pemerintah untuk memerintah atau bertindak. Secara konstitusional, landasan hukum bertindak pejabat publik di Indonesia adalah UUD 1945 berikut peraturan pelaksanaannya sesuai tata urutan menurut Pasal 7 UU Nomor 12 Tahun 2011 tentang Pembentukan Peraturan Perundang-Undangan. Hal tersebut disebut sebagai asas legalitas yang merupakan unsur universal konsep negara hukum. Oleh karena itu, kekuasaan pemerintah tidak

${ }^{6}$ Kamus Besar Bahasa Indonesia, Departemen Pendidikan Nasional Balai Pustaka, Jakarta, 2005, hlm. 1272.

${ }^{7}$ Henry Campbell Black, Black's Law Dictionary, West Publishing, 1990, hlm. 133.

8 Mohammad Sahlan, "Unsur Menyalahgunakan Kewenangan dalam Tindak Pidana Korupsi sebagai Kompetensi Absolut Peradilan Administrasi”, Jurnal Ius Quia Iustum, No. 2 Vol. 23 April 2016, 271 - 293, hlm. 276. 
dapat lepas dari perkembangan asas legalitas yang telah dimulai sejak munculnya konsep negara hukum klasik dan modern. Namun demikian, seiring dengan perkembangan konsep negara hukum, pejabat tata usaha negara di samping bertindak berdasarkan ketentuan peraturan perundang-undangan yang berlaku, juga wajib bertindak berdasarkan asas-asas umum yang baik. Asas-asas umum pemerintahan yang baik (AAUPB) ini sudah lazim diterapkan dalam negara yang mengklaim dirinya negara hukum. Paham ini disebut dengan negara hukum kesejahteraan.

Paham negara hukum kesejahteraan sering juga disebut sebagai negara hukum modern dalam arti material. Apabila diamati, konsepsi negara hukum kesejahteraan sesungguhnya merupakan pengembangan dari konsepsi negara hukum materil. Dalam upaya menciptakan kesejahteraan rakyat muncul konsepsi negara hukum kesejahteraan yang diintrodusir oleh Otto Bar sebagaimana dikutip oleh Amran Muslimin', bahwa:

Negara hukum modern menjadi negara yang bersifat Negara Kebudayaan (Cultuurstaat) atau Negara Kesejahteraan (Welvaarstaat). Negara dianggap sebagai perusahaan yang medatangkan manfaat bagi rakyat, karena menyelenggarakan kepentingan umum dan melalui saluran-saluran hukum (Wetmatigheid van administratie). Saluran-saluran hukum ini dibuat oleh Raja bersama-sama dengan rakyat. Jadi rakyat ikut menentukan kepentingan umum, bukan raja sendiri seperti dalam Polizeistaat.

Berdasarkan pendapat di atas, tampak bahwa negara dipersamakan dengan perusahaan yang mendatangkan manfaat bagi rakyat. Raja dan rakyat secara bersama-sama menentukan kepentingan umum. Bagir Manan ${ }^{10}$ mengatakan bahwa konsep negara hukum kesejahteraan, adalah:

“Negara atau pemerintah tidak semata-mata sebagai penjaga keamanan atau ketertiban masyarakat, tetapi pemikul utama tanggung jawab mewujudkan keadilan sosial, kesejahteraan umum dan sebesar-besarnya kemakmuran rakyat".

Tentang keikutsertaan rakyat turut menentukan kepentingan umum tidak terlepas dari pemikiran Jean Jacques Rousseau yang terkenal dengan teorinya yaitu: Teori kontrak sosial (contract social) atau perjanjian masyarakat. J J. Rousseau

9 Amrah Muslimin, Beberapa Asas-asas Dan Pengetian-Pengertian Pokok tentang Administrasi Dan Hukum Administrasi, Alumni, Bandung, 1982, hlm. 87.

${ }^{10}$ Bagir Manan, Politik Perundang-undangan Dalam Rangka Mengantisipasi Liberalisme Perekonomian, FH. UNILA, Bandar Lampung, 1996, hlm. 9. 
berpendapat bahwa kekuasan tertinggi dalam negara ada pada rakyat, jadi yang berdaulat adalah rakyat, sedangkan penguasa-penguasa negara hanya merupakan wakil-wakil rakyat. Perwujudan dari kedaulatan rakyat itu dituangkan atau menjelma di dalam konstitusi. ${ }^{11}$

Indonesia berdasarkan UUD 1945 menganut paham negara hukum kesejahteraan. Karena itu, pejabat tata usaha negara dalam bertindak di samping berdasarkan ketentuan hukum (peraturan perundang-undangan), juga harus bertindak berdasarkan asas-asas umum pemerintahan yang baik. Apabila kedua hal itu disimpangi, keputusan tata usaha negara itu batal dan/atau harus dibatalkan.

Di dalam Pasal 1 angka 1 Undang-Undang Nomor 30 Tahun 2014 tentang Administrasi Pemerintahan disebutkan bahwa Administrasi Pemerintahan adalah tata laksana dalam pengambilan keputusan dan/atau tindakan oleh badan dan/atau pejabat pemerintahan. Bertalian dengan itu, Hukum Administrasi Negara adalah merupakan dasar dan/atau kaidah penuntun bagi pejabat tata usaha negara dalam menjalankan pemerintahan (administrasi pemerintahan). Tindakan tersebut biasanya dituangkan dalam sebuah keputusan, yang disebut dengan keputusan administrasi pemerintahan (keputusan tata usaha negara).

\section{Penyelesaian Penyalahgunaan Wewenang}

Seperti disebutkan dalam pembahasan sebelumnya bahwa wewenang itu merupakan kekuasaan (hak) yang diberikan kepada pejabat publik atau pemerintah untuk memerintah atau bertindak. Dalam menjalankan kewenangan itu ada kewajiban bagi pejabat publik untuk mematuhi aturan hukum. Sebab, seperti dikemukakan oleh Artidjo Alkostar12 bahwa timbulnya korupsi tidak terlepas dari kekuasaan yang tidak terkontrol atau penyalahgunaan kekuasaan. Karena itu, ada batasan-batasan yang patut dipatuhi oleh pemegang wewenang itu.

Menurut Pasal 15 UU Nomor 30 Tahun 2014 bahwa wewenang itu dibatasi oleh masa atau tenggang waktu, wilayah daerah berlaku, dan cakupan bidang atau materi

11 Terpetik dari Muhamat Yamin, Proklamasi dan Konstitusi Republik Indonesi, Penerbit Djambatan, Djakarta/Amesterdam, 1951, hlm.62-63.

12 Artidjo Alkostar, "Korelasi Korupsi Politik Dengan Hukum dan Pemerintahan di Negara Modern (Telaah tentang Praktik Korupsi Politik dan Penanggulangannya)", Jurnal Hukum Ius Quia Iustum, No. Edisi khusus, Vol. 16 Oktober 2009, $155-179$ 
wewenang. Badan dan/atau Pejabat Pemerintahan yang telah berakhir masa atau tenggang waktu wewenang tidak dibenarkan mengambil Keputusan dan/atau Tindakan. Karena itu, sesuai Pasal 17 UU Nomor 30 Tahun 2014 disebutkan, bahwa Badan dan/atau Pejabat Pemerintahan dilarang menyalahgunakan wewenang. Larangan penyalahgunaan wewenang meliputi: a) larangan melampaui wewenang; b) larangan mencampuradukkan wewenang; dan/atau c) larangan bertindak sewenang-wenang. Selanjutnya di dalam Pasal 18 disebutkan, bahwa:

(1) Badan dan/atau Pejabat Pemerintahan dikategorikan melampaui wewenang sebagaimana dimaksud dalam Pasal 17 ayat (2) huruf a apabila Keputusan dan/atau Tindakan yang dilakukan:

a. melampaui masa jabatan atau batas waktu berlakunya wewenang;

b. melampaui batas wilayah berlakunya wewenang; dan/atau

c. bertentangan dengan ketentuan peraturan perundang-undangan.

(2) Badan dan/atau Pejabat Pemerintahan dikategorikan mencampuradukkan wewenang sebagaimana dimaksud dalam Pasal 17 ayat (2) huruf b apabila Keputusan dan/atau Tindakan yang dilakukan:

a. di luar cakupan bidang atau materi wewenang yang diberikan; dan/atau

b. bertentangan dengan tujuan wewenang yang diberikan.

(3) Badan dan/atau Pejabat Pemerintahan dikategorikan bertindak sewenangwenang sebagaimana dimaksud dalam Pasal 17 ayat (2) huruf c apabila Keputusan dan/atau Tindakan yang dilakukan:

a. tanpa dasar kewenangan; dan/atau

b. bertentangan dengan Putusan Pengadilan yang berkekuatan hokum tetap.

Apabila ada keputusan yang dikeluarkan melampaui kewenangannya, di dalam Pasal 19 disebutkan, bahwa:

(1) Keputusan dan/atau Tindakan yang ditetapkan dan/atau dilakukan dengan melampaui Wewenang sebagaimana dimaksud dalam Pasal 17 ayat (2) huruf a dan Pasal 18 ayat (1) serta Keputusan dan/atau Tindakan yang ditetapkan dan/atau dilakukan secara sewenang-wenang sebagaimana dimaksud dalam Pasal 17 ayat (2) huruf c dan Pasal 18 ayat (3) tidak sah apabila telah diuji dan ada Putusan Pengadilan yang berkekuatan hukum tetap.

(2) Keputusan dan/atau Tindakan yang ditetapkan dan/atau dilakukan dengan mencampuradukkan wewenang sebagaimana dimaksud dalam Pasal 17 ayat (2) huruf b dan Pasal 18 ayat (2) dapat dibatalkan apabila telah diuji dan ada Putusan Pengadilan yang berkekuatan hukum tetap.

Untuk mengawasi badan dan/atau pejabat pemerintah dalam menjalankan wewenangnya dibentuk APIP. Hal itu sesuai dengan ketentuan Pasal 20, yang mengatakan, bahwa: 
(1) Pengawasan terhadap larangan penyalahgunaan wewenang sebagaimana dimaksud dalam Pasal 17 dan Pasal 18 dilakukan oleh aparat pengawasan intern pemerintah.

(2) Hasil pengawasan aparat pengawasan intern pemerintah sebagaimana dimaksud pada ayat (1) berupa:

a. tidak terdapat kesalahan;

b. terdapat kesalahan administratif; atau

c. terdapat kesalahan administratif yang menimbulkan kerugian keuangan negara.

(3) Jika hasil pengawasan aparat intern pemerintah berupa terdapat kesalahan administratif sebagaimana dimaksud pada ayat (2) huruf $b$, dilakukan tindak lanjut dalam bentuk penyempurnaan administrasi sesuai dengan ketentuan peraturan perundang-undangan.

(4) Jika hasil pengawasan aparat intern pemerintah berupa terdapat kesalahan administratif yang menimbulkan kerugian keuangan negara sebagaimana dimaksud pada ayat (2) huruf c, dilakukan pengembalian kerugian keuangan negara paling lama 10 (sepuluh) hari kerja terhitung sejak diputuskan dan diterbitkannya hasil pengawasan.

(5) Pengembalian kerugian negara sebagaimana dimaksud pada ayat (4) dibebankan kepada Badan Pemerintahan, apabila kesalahan administratif sebagaimana dimaksud pada ayat (2) huruf c terjadi bukan karena adanya unsur penyalahgunaan Wewenang.

(6) Pengembalian kerugian negara sebagaimana dimaksud pada ayat (4) dibebankan kepada Pejabat Pemerintahan, apabila kesalahan administratif sebagaimana dimaksud pada ayat (2) huruf c terjadi karena adanya unsur penyalahgunaan Wewenang.

Berdasarkan ketentuan di atas tampak bahwa pejabat tata usaha negara dilarang menyalahgunakan kewenangan. Dalam mengawasi pejabat tata usaha negara dalam menjalankan kewenangannya dibentuk APIP. Dalam hal ini, APIP diberi kewenangan dalam menyelesaikan penyalahgunaan wewenang. Di samping penyelesaian melalui APIP, mekanisme penyelesaiannya dapat dilakukan dengan mengajukan permohonan ke Pengadilan Tata Usaha Negara (Pasal 21 UU No. 30. Tahun 2014). Di mana, apa bila dalam penyalahgunaan wewenang itu terjadi kerugian negara, pejabat tata usaha negara harus mengembalikan kerugian negara itu paling lama 10 hari kerja terhitung sejak diputuskan dan diterbitkannya hasil pengawasan.

Secara yuridis, keberadaan keputusan APIP adalah sah dan mengikat, karena dibuat oleh pejabat tata usaha negara. Begitu juga dengan keputusan PTUN, juga 
sah dan mengikat. Karena itu, baik keputusan APIP maupun keputusan PTUN harus dihargai dan dipatuhi ${ }^{13}$.

Dalam menyelesaikan penyalahgunaan wewenang yang menimbulkan kerugian keuangan negara juga diatur dalam UU No. 1 Tahun 2004 tentang Perbendaharaan Negara. Pasal 1 angka 22 UU No. 1 Tahun 2004 mengatakan, bahwa: Kerugian Negara/Daerah adalah kekurangan uang, surat berharga, dan barang yang nyata dan pasti jumlahnya sebagai akibat perbuatan melawan hukum baik sengaja maupun lalai.

Terkait penyelesaian kerugian negara, di dalam Pasal 59 UU No. 1 Tahun 2004 disebutkan, bahwa:

(1) Setiap kerugian negara/daerah yang disebabkan oleh tindakan melanggar hukum atau kelalaian seseorang harus segera diselesaikan sesuai dengan ketentuan perundang-undangan yang berlaku.

(2) Bendahara, pegawai negeri bukan bendahara, atau pejabat lain yang karena perbuatannya melanggar hukum atau melalaikan kewajiban yang dibebankan kepadanya secara langsung merugikan keuangan negara, wajib mengganti kerugian tersebut.

(3) Setiap pimpinan kementerian negara/lembaga/kepala satuan kerja perangkat daerah dapat segera melakukan tuntutan ganti rugi, setelah mengetahui bahwa dalam kementerian negara/lembaga/satuan perangkat daerah yang bersangkutan terjadi kerugian akibat perbuatan dari pihak mana pun.

Di dalam Pasal 60 kemudian disebutkan, bahwa:

(1) Setiap kerugian negara wajib dilaporkan oleh atasan langsung atau kepala kantor kepada menteri/pimpinan lembaga dan diberitahukan kepada Badan Pemeriksa Keuangan selambat-lambatnya 7 (tuju) hari kerja setelah kerugian negara itu diketahui.

(2) Segera setelah kerugian negara tersebut diketahui, kepada bendahara, pegawai negeri bukan bendahara, atau pejabat lain yang nyata-nyata melanggar hukum atau melalaikan kewajibannya sebagaimana dimaksud dalam Pasal 52 ayat (2) segera dimintakan surat pernyataan kesanggupan dan/atau pengakuan bahwa kerugian tersebut menjadi tanggung jawabnya dan bersedia mengganti kerugian negara dimaksud.

(3) Jika surat keterangan tanggung jawab mutlak tidak mungkin diperoleh atau tidak dapat menjamin pengembalian kerugian negara, menteri/pimpinan lembaga yang bersangkutan segera mengeluarkan surat keputusan pembebanan penggantian kerugian sementara kepada yang bersangkutan.

13 Marojahan JS Panjaitan, Pertanggungjawaban Kerugian Negara dalam Persfektif Hukum Administrasi Negara, dalam Prosiding Seminar Nasional Pertanggungjawaban Hukum Terhadap Pengelolaan Keuangan Negara, Fakultas Hukum Universitas Jenderal Soedirman Purwokerto, 2017, hlm. 166-165. 
Selanjutnya dalam Pasal 61 disebutkan, bahwa:

(1) Setiap kerugian daerah wajib dilaporkan oleh atasan langsung atau kepala satuan kerja perangkat daerah kepada gubernur/bupati/walikota dan diberitahukan kepada Badan Pemeriksa Keuangan selambat-lambatnya 7 (tujuh) hari kerja setelah kerugian daerah itu diketahui.

(2) Segera setelah kerugian daerah tersebut diketahui, kepada bendahara, pegawai negeri sipil bukan bendahara, atau pejabat lain yang nyata-nyata melanggar hukum atau melalaikan kewajibannya sebagaimana dimaksud dalam Pasal 59 ayat (2) dapat segera dimintakan surat pernyataan kesanggupan dan/atau pengakuan bahwa kerugian tersebut menjadi tanggung jawabnya dan bersedia mengganti kerugian daerah dimaksud.

(3) Jika surat keterangan tanggung jawab mutlak tidak mungkin diperoleh atau tidak dapat menjamin pengembalian kerugian daerah, gubernur/bupati/ walikota/ yang bersangkutan segera mengeluarkan surat keputusan pembebanan penggantian kerugian sementara kepada yang bersangkutan.

Di dalam Pasal 62 juga disebutkan, bahwa:

(1) Pengenaan ganti kerugian negara/daerah terhadap bendahara ditetapkan oleh Badan Pemeriksa Keuangan.

(2) Apabila dalan pemeriksaan kerugian negara/daerah sebagaimana dimaksud pada ayat (1) ditemukan unsur pidana, Badan Pemeriksa Keuangan menindaklanjutinya sesuai dengan peraturan perundang-undangan yang ada.

(3) Ketentuan lebih lanjut tentang pengenaan ganti kerugian negara terhadap bendahara diatur dalam undang-undang mengenai pemeriksaaan pengelolaan dan tanggung jawab keuangan negara.

Pasal 63 mengatakan, bahwa: Pengenaan ganti kerugian negara/daerah terhadap pegawai negeri bukan bendahara ditetapkan oleh menteri/pimpinan lembaga/gubernur/bupati/walikota. Tatacara tuntutan ganti kerugian negara/daerah diatur dengan peraturan perundang-undangan. Hanya seperti dikatakan dalam Pasal 64, bahwa: Bendahara, pegawai negeri bukan bendahara, dan pejabat lain yang telah ditetapkan untuk mengganti kerugian negara/daerah dapat dikenai sanksi administratif dan/atau sanksi pidana.Putusan pidana tidak membebaskan dari tuntuan ganti rugi.

Tentang batas waktu penggantian ganti rugi dalam Pasal 65 disebutkan, bahwa: "Kewajiban bendahara, pegawai negeri bukan bendahara, atau pejabat lain untuk membayar ganti rugi, menjadi kedaluwarsa jika dalam waktu 5 tahun sejak diketahuinya kerugian tersebut atau dalam waktu 8 tahun sejak terjadinya kerugian tidak dilakukan penuntutan ganti rugi terhadap yang bersangkutan." 
Berdasarkan ketentuan Pasal 65 di atas, batas waktu ganti rugi itu ditentukan yakni 5 tahun sejak diketahuinya kerugian dan 8 tahun sejak terjadinya kerugian. Jadi, ada dua acara dalam menentukan batas waktunya, yakni: a. Sejak diketahui; dan b. Sejak terjadi kerugian. Apabila badan dan/atau pejabat pemerintah tidak mampu mengembalikan kerugian negara, di dalam Pasal 66 disebutkan, bahwa :

(1) Dalam hal bendahara, pegawai negeri bukan bendahara, atau pejabat lain yang dikenai tuntutan ganti kerugian negara/daerah berada dalam pengampuan, melarikan diri, atau meninggal dunia, penuntutan dan penagihan terhadapnya beralih kepada penganpu/yang memperoleh hak/ahli waris, terbatas pada kekayaan yang dikelola atau diperolehnya, yang berasal dari bendahara, pegawai negeri bukan bendahara, atau pejabat lain yang bersangkutan.

(2) Tanggung jawab pengampu/yang memperoleh hak/ahli waris untuk membayar ganti kerugian negara/ daerah sebagaiman dimaksud pada ayat (1) menjadi hapus apabila dalam waktu 3 (tiga) tahun sejak keputusan pengadilan yang menetapkan pengampuan kepada bendahara, pegawai negeri bukan bendahara, atau pejabat lain yang bersangkutan, atau sejak bendahara, pegawai negeri bukan bendahara, atau pejabat lain yang bersangkutan diketahui melarikan diri atau meninggal dunia, pengampu/yang memperoleh hak/ahli waris tidak diberitahu oleh pejabat yang berwenang mengenai adanya kerugian negara/daerah.

Selanjutnya di dalam Pasal 67 disebutkan, bahwa :

(1) Ketentuan penyelesaian kerugian negara/daerah sebagaimana diatur dalam Undang-undang ini berlaku pula untuk uang dan/atau barang bukan milik negara/daerah, yang berada dalam penguasaan bendahara, pegawai negeri bukan bendahara, atau pejabat lain yang digunakan dalam penyelenggaraan tugas pemerintahan.

(2) Ketentuan penyelesaian kerugian negara/daerah dan badan-badan lain yang menyelenggarakan pengelolaan keuangan negara, sepanjang tidak diatur dalam undang-undang tersendiri.

Apabila penyelesaian kerugian negara seperti disebutkan di atas diperhatikan, ternyata ada perbedaan dengan UU No. 30 Tahun 2014. Menurut UU No. 30 Tahun 2014 dalam menyelesaikan kerugian negara itu dibentuk sebuah badan yakni : APIP. Badan ini bertugas untuk memeriksa pejabat pemerintah yang melanggar ketentuan Pasal 17 UU No. 30 Tahun 2014. Jika hasil pengawasan APIP terdapat kesalahan administratif sebagaimana dimaksud pada ayat (2) huruf $b$, dilakukan tindak lanjut dalam bentuk penyempurnaan administrasi sesuai dengan ketentuan peraturan perundang-undangan. Begitu juga jika hasil APIP berupa terdapat kesalahan administratif yang menimbulkan kerugian keuangan negara 
sebagaimana dimaksud pada ayat (2) huruf c, dilakukan pengembalian kerugian keuangan negara paling lama 10 hari kerja terhitung sejak diputuskan dan diterbitkannya hasil pengawasan.

Pengembalian kerugian negara sebagaimana dimaksud pada ayat dibebankan kepada Badan Pemerintahan, apabila kesalahan administratif sebagaimana dimaksud pada ayat (2) huruf $\mathrm{c}$ terjadi bukan karena adanya unsur penyalahgunaan Wewenang. Pengembalian kerugian negara sebagaimana dimaksud pada ayat (4) dibebankan kepada Pejabat Pemerintahan, apabila kesalahan administratif sebagaimana dimaksud pada ayat (2) huruf c terjadi karena adanya unsur penyalahgunaan wewenang. Sedangkan menurut UU No. 1 Tahun 2004 yang menentukan terjadi kerugian negara itu adalah BPK. Apabila dalan pemeriksaan kerugian negara/daerah ditemukan unsur pidana, Badan Pemeriksa Keuangan (BPK) menindaklanjutinya sesuai dengan peraturan perundangundangan yang ada (Pasal 62 ayat (2) UU No. 1 Tahun 2004).

Bertalian dengan proses pengembalian kerugian negara menurut UU No. 30 Tahun 2014 seperti disebutkan di atas, hal tersebut menjadi kontroversi dengan ketentuan Pasal 4 UU No. 31 Tahun 1999 tentang Pemberantasan Tindak Pidana Korupsi. Sebagaimana disebut dalam Pasal 4 UU No. 30 Tahun 1999, bahwa: Pengembalian kerugian keuangan negara atau perekonomian negara tidak menghapuskan dipidananya pelaku tindak pidana sebagaimana dimaksud dalam Pasal 2 dan Pasal 3. Atas dasar itu, Mohammad Sahlan ${ }^{14}$ mengatakan bahwa lahirnya Undang-Undang Nomor 30 Tahun 2014 tentang Administrasi Pemerintahan (UU Administrasi Pemerintahan) yang diundangkan pada tanggal 17 Oktober 2014 dan dimaksudkan untuk mengatur reformasi birokrasi, sebagai sarana penanggulangan tipikor melalui pendekatan pencegahan (preventif). Merupakan contoh peraturan perundang-undangan terkait dengan pemberantasan Tipikor yang salah satu normanya bertentangan (conflict of norm) dengan salah satu norma dalam UU Nomor 31 Tahun 1999 tentang Pemberantasan Tindak Pidana Korupsi, sebagaimana telah diubah dengan UU Nomor 20 Tahun 2001 (UU

\footnotetext{
14 Mohammad Sahlan, "Kewenangan Peradilan Tipikor Pasca Berlakunya Undang-Undang No. 30 Tahun 2014 Tentang Administrasi Pemerintahan", Jurnal Arena Hukum, Universitas Brawidjaya, Volume 9, Nomor 2, Agustus 2016, hlm. 168.
} 
Pemberantassan Tipikor) dan UU Nomor 46 Tahun 2009 tentang Pengadilan Tindak Pidana Korupsi (UU Pengadilan Tipikor), yang merupakan instrument hukum dalam upaya penanggulanggan korupsi melalui pendekatan penindakan (represif). Conflict of norm terjadi antara Pasal 5 dan Pasal 6 UU Pengadilan Tipikor Jo. Pasal 3 UU Pemberantasan Tipikor dengan ketentuan Pasal 21 ayat (1) jo. Pasal 1 angka 188 jo. Pasal 17 UU Administrasi Pemerintahan, berkenaan dengan kompetensi absolut untuk memeriksan dan memutus unsur "menyalahgunakan kewenangan" karena jabatan dalam Tipikor, yang konsepnya oleh beberapa ahli hukum dipandang sama dengan konsep "penyalahgunaan wewenang" dalam UU Administrasi Pemerintahan yang kewenangan untuk memeriksa dan memutus masalah tersebut diberikan kepada Peradilan Tata Usaha Negara (PTUN).

Permasalahannya adalah apabila dalam penyalahgunaan wewenang yang dilakukan badan dan/atau pejabat pemerintah yang merugikan keuangan negara itu sudah diselesaikan oleh APIP dan bahkan sudah ada putusan Pengadilan Tata Usaha Negara yang sudah mempunyai kekuatan hukum tetap untuk menyelesaikan pengembalian kerugian negara itu, masih dapatkah Komisi Pemberantasan Korupsi, Kejaksaan, dan POLRI mengusutnya kembali.

Terhadap permasalahan di atas patut dilihat ketentuan Pasal 62 ayat (2) UU No. 1 Tahun 2004 yang menyebutkan, bahwa: "Apabila dalan pemeriksaan kerugian negara/daerah sebagaimana dimaksud pada ayat (1) ditemukan unsur pidana, Badan Pemeriksa Keuangan menindaklanjutinya sesuai dengan peraturan perundang-undangan yang ada". Kalau mengacu kepada ketentuan Pasal 62 ayat (2) UU No. 1 Tahun 2004 tentang Perbendaharaan Negara di atas, penggantian ganti rugi tidak menutup tuntutan pidana. Artinya bahwa pengembalian kerugian negara tidak menutup tuntutan pidana. Penulis sependapat dengan ketentuan UU No. 1 Tahun 2004 dan Pasal 4 UU No. 31 Tahun 1999 yang mengatakan, bahwa pengembalian kerugian keuangan negara atau perekonomian negara tidak menghapuskan dipidananya pelaku tindak pidana. Karena itu, pengembalian kerugian negara sebagaimana dimaksusd oleh UU No. 30 Tahun 2014 tidak menghapus tuntutan pidananya. APIP harus melaporkan pejabat negara yang terbukti melakukan penyalahgunaan wewenang yang merugikan keuangan negara kepada penegak hukum lainnya untuk diselesaikan secara pidana, 
sebagaimana dilakukan oleh BPK. Dalam hal ini, bisa kepada POLRI, Kejaksaan, dan KPK. Hasil pemeriksaan APIP dan Keputusan Tata Usaha Negara itu dijadikan sebagai bukti yang tidak perlu diuji lagi kebenarannya oleh Majelis Hakim dalam peradilan yang diselenggarakan untuk itu. Hal ini memang tidak diatur di dalam UU No. 30 Tahun 2014. Tetapi, dengan mengadopsi ketentuan Pasal 62 ayat (2) UU No 1 Tahun 2004 tentang Perbendaharaan Negara, APIP dapat melapor pejabat pemerintah itu ke peradilan pidana. Cara ini malah lebih memudahkan dalam penanggulangan tindak pidana korupsi.

Bertalian dengan fungsi APIP yang begitu strategis dalam menangani penyalahgunaan wewenang yang merugikan keuangan negara, sangat diharapkan bekerja secara aktif. APIP dalam mencegah dan menanggulangi tindak pidana korupsi dapat bekerjasama dengan penegak hukum lainnya, agar tidak terjadi tumpangtindih dalam menyelesaikannya. Karena itu, kelembagaan APIP harus segera diwujudkan dan APIP haruslah independen serta bekerja secara objektif dan professional. Sebaiknya APIP itu berada di bawah kementerian terkait, agar bisa bekerja secara objektif dan professional.

\section{Penutup}

Penyelesaian penyalahgunaan wewenang yang dilakukan oleh Badan dan/atau Pejabat Pemerintahan yang menimbulkan kerugian negara berdasarkan UU. No. 30 Tahun 2014 dilakukan oleh Aparat Pengawas Interen Pemerintahan (APIP) dan Pengadilan Tata Usaha Negara. Apabila dalam pemeriksaan tersebut ditemukan kerugian negara, pejabat yang melakukan penyalahgunaan wewenang tersebut mengembalikan kerugian negara.

Keputusan Aparat Pengawas Interen Pemerintahan (APIP) dan putusan Pengadilan Tata Usaha Negara dalam menyelesaikan penyalahgunaan wewenang yang dilakukan oleh Badan dan/atau Pejabat Pemerintahan yang merugikan keuangan negara sebagaimana diatur dalam UU No. 30 Tahun 2014 mempunyai kekuatan mengikat dan wajib dipatuhi dan dilaksanakan. Tetapi, sesuai Pasal 4 UU No. 31 Tahun 1999 pengembalian kerugian negara tidak menghapuskan perbuatan pidananya. Berkas pemeriksaan Aparat Pengawas Interen Pemerintah (APIP) serta 
Keputusan Pengadilan Tata Usaha Negara dapat dijadikan sebagai barang bukti untuk menyelesaikan pertanggungjawaban pidananya.

Aparat Pengawas Interen Pemerintah (APIP) seharusnya proaktif mengawasi Badan dan/atau Pejabat Pemerintahan dalam mengambil kebijakan agar kerugian negara tidak terjadi. Ketika Aparat Pengawas Interen Pemerintah (APIP) menemukan ada penyalahgunaan wewenang yang merugikan keuangan negara yang dilakukan oleh Badan dan/atau Pejabat Pemerintahan sebaiknya mengambil inisiatif untuk melaporkan Badan dan/atau Pejabat Pemerintahan itu ke penegak hukum, agar perbuatannya itu diusut secara pidana.

\section{Daftar Pustaka}

\section{Buku}

Black, Henry Campbell, Black's Law Dictionary, West Publishing, 1990.

Fahruddin, Irfan, Pengawasan Peradilan Administrasi Terhadap Tindakan Pemerintah, Alumni, Bandung, 2004.

Harahap, Zairin, Hukum Acara Peradilan Tata Usaha Negara, PT. RajaGrafindo Persada, Jakarta, 2010.

Muslimin, Amrah, Beberapa Asas-asas Dan Pengetian-Pengertian Pokok tentang Administrasi Dan Hukum Administrasi, Alumni, Bandung, 1982.

Manan, Bagir, Politik Perundang-undangan Dalam Rangka Mengantisipasi Liberalisme Perekonomian, FH. UNILA, Bandar Lampung, 1996.

Panjaitan, Marojahan JS., Pembentukan \& Perubahan Undang-Undang Berdasarkan UUD 1945, Pustaka Reka Cipta, Bandung, 2017.

- Pertanggungjawaban Kerugian Negara dalam Persfektif Hukum Administrasi Negara, dalam Prosiding Seminar Nasional Pertanggungjawaban Hukum Terhadap Pengelolaan Keuangan Negara, Fakultas Hukum Universitas Jenderal Soedirman Purwokerto, 2017.

Ridwan, H. Juniarso dan Ahmad Sodik Sudrajat, Hukum Administrasi Negara dan Kebijakan Layanan Publik, Nuansa Cendikia, Bandung, 2014.

Tjandra, Riawan, Teori dan Praktik Peradilan Tata Usaha Negara, Cahaya Atma Pustaka, Yogyakarta, 2011.Lihat pula Zairin Harahap, Hukum Acara Peradilan Tata Usaha Negara, PT. RajaGrafindo Persada, Jakarta, 2010.

Yamin, Muhamat, Proklamasi dan Konstitusi Republik Indonesi, Penerbit Djambatan, Djakarta/ Amesterdam, 1951.

\section{Jurnal}

Alkostar, Artidjo, "Korelasi Korupsi Politik Dengan Hukum dan Pemerintahan di Negara Modern (Telaah tentang Praktik Korupsi Politik dan 
Penanggulangannya)", Jurnal Hukum Ius Quia Iustum, No. Edisi Khusus, Vol. 16 Oktober 2009.

Rasul, Sjahrudin, Penerapan Good Governance di Indonesia dalam Upaya Pencegahan Tindak Pidana Korupsi, Jurnal Mimbar Hukum Fakultas Hukum Universitas Gadjah Mada, Volume 21 Nomor 3, Oktober 2009.

Respationo, H.M. Soerya, "Penyelenggaraan Pemerintah yang Bersih Menuju Zona Integritas Wilayah Bebas Korupsi", Jurnal, Masalah-Masalah Hukum, Fakultas Hukum Universitas Diponegoro, Jilid 42 No. 1 Tahun 2013.

Sahlan, Mohammad, Unsur Menyalahgunakan Kewenangan dalam Tindak Pidana Korupsi sebagai Kompetensi Absolut Peradilan Administrasi, Jurnal Ius Quia Iustum, No. 2 Vol. 23 April 2016.

Kewenangan Peradilan Tipikor Pasca Berlakunya Undang-Undang No. 30 Tahun 2014 Tentang Administrasi Pemerintahan, Jurnal, Arena Hukum, Universitas Brawidjaya, Volume 9, Nomor 2, Agustus 2016.

\section{Kamus}

Kamus Besar Bahasa Indonesia, Departemen Pendidikan Nasional Balai Pustaka, Jakarta, 2005.

\section{Peraturan Perundang-Undangan}

Undang-Undang Dasar Republik Indonesia Tahun 1945.

Undang-Undang Nomor 5 Tahun 1986 tentang Peradilan Tata Usaha Negara.

Undang-Undang Nomor 31 Tahun 1999 tentang Pemberantasan Tindak Pidana Korupsi.

Undang-Undang Nomor 17 Tahun 2003 tentang Keuangan Negara.

Undang-Undang Nomor 1 Tahun 2004 tentang Perbendaharaan Negara.

Undang-Undang Nomor 9 Tahun 2004 tentang Perubahan atas Undang-Undang Nomor 5 Tahun 1986 tentang Peradilan Tata Usaha Negara.

Undang-Undang Nomor 30 Tahun 2014 tentang Administrasi Pemerintahan. 